\title{
PASH: STROMAL AND PSEUDOANGIOMATOUS HYPERPLASIA — SURGICAL TREATMENT USING ONCOPLASTIC TECHNIQUES - THOREK AND DERMAL FLAP
}

\author{
PASH: hiperplasia estromal e pseudoangiomatosa - \\ tratamento utilizando técnicas oncopásticas - Thorek e dermal flap
}

\author{
Ana Carolina Guglielmelli Mendonça1*, Raffaela Levy de Andrade², Douglas de Miranda Pires³
}

\section{ABSTRACT}

Pseudoangiomatousstromal hyperplasia (PASH) is a benign and infrequentmammary pathology, characterized byabnormal proliferation of stromal cells forming a complex network of channels interconnected by vascular spaces, delineated by fusiform cells, originating from myofibroblastic cells. It is commonly found in breast biopsies as an incidental finding and, more rarely, it can form a nodular, tumorlike mass or exhibit a pattern of diffuse involvement of the breast parenchyma. It affects women aged between 18 and 45 years old and is related to hormonal stimulation. In most cases, PASH shows slow growth. The treatment recommended by most authors is a broad excision of the lesion, with free margins to avoid local recurrences. Surgical resection combined with breast reconstruction techniques allows the incorporation of concepts and techniques that respect aesthetics and improve women's quality of life. This study aimed to report the case of a 40-year-old patient with multiple bilateral breast nodules, associated with ptotic hypertrophic mastopathy, treated by adenectomy and immediate reconstruction with mammary prosthesis using Thorek's technique. The patient presented a good postoperative evolution, with excellent cosmetic results and no evidence of disease after 19 months of diagnosis.

KEYWORDS: Hyperplasia; neoplasms; breast; reconstructive surgical procedures.

\section{RESUMO}

A hiperplasia estromal pseudoangiomatosa (pseudoangiomatous stromal hyperplasia — PASH) é uma patologia mamária benigna e pouco frequente, caracterizada por proliferação anormal de células estromais que formam uma rede complexa de canais interligados por espaços vasculares, delineados por células fusiformes, oriundas de células miofibroblásticas. Comumente encontrado em biópsias de mama como achado incidental e, mais raramente, por formar uma massa nodular de aparência tumoral ou exibir um padrão de envolvimento difuso do parênquima mamário. Afeta mulheres entre as idades de 18 e 45 anos e está ligada a estímulo hormonal. Na maioria dos casos, essa patologia mostra crescimento lento. O tratamento recomendado pela maioria dos autores é uma excisão ampla da lesão, com margens livres para evitar as recidivas locais. O tratamento cirúrgico aliado à reconstrução mamária permite incorporar conceitos e técnicas que respeitam a estética e melhoram a qualidade de vida da mulher. O objetivo deste trabalho foi relatar o caso de uma paciente de 40 anos com múltiplos nódulos mamários bilaterais associados à mastopatia hipertrófica ptótica, tratada por adenectomia e reconstrução imediata com prótese mamária utilizando a técnica de Thorek. A paciente mantém-se em boa evolução pós-operatória, com excelente resultado cosmético e sem evidência de doença após 19 meses de diagnóstico.

PALAVRAS-CHAVE: Hiperplasia; neoplasia benigna; mama; procedimentos cirúrgicos reconstrutivos.

Study carried out at Santa Casa de Misericórdia de Belo Horizonte - Belo Horizonte (MG), Brazil.

${ }^{1}$ Hospital São Francisco de Assis - Belo Horizonte (MG), Brazil.

${ }^{2}$ Hospital Santa Casa de Misericórdia de Belo Horizonte - Belo Horizonte (MG), Brazil.

${ }^{3}$ Mastology Clinic, Santa Casa de Belo Horizonte, Hospital Santa Casa de Misericórdia de Belo Horizonte - Belo Horizonte (MG), Brazil.

*Corresponding author: anacarolinamasto@gmail.com

Conflict of interests: nothing to declare.

Received on: 06/11/2017. Accepted on: 03/05/2018 


\section{INTRODUCTION}

Pseudoangiomatous stromal hyperplasia (PASH) is a benign breast disease described for the first time in 1986 by Vuitch et al. ${ }^{1}$. From 1986 until 2007, less than 150 reported cases of tumorforming PASH were found ${ }^{2}$. In contrast, focal PASH, which does not form tumors, may be an incidental microscopic finding in up to $23 \%$ of breast biopsies ${ }^{3}$. Initially considered to be a variant of mammary hamartomas, this lesion is currently considered a benign proliferation of stromal myofibroblasts, expressing CD34, vimentin, actin, smooth muscle desmin and bcl-2, but not endothelial markers (CD31, Factor VIII), S100 or cytokeratin. The clinical-pathological spectrum ranges from incidental focal microscopic findings to clinically and mammographically evident mammary masses. It is histologically characterized by the interaction of angular spaces and slits aligned by thin spindle cells and surrounded by dense collagen stroma. It affects women in the age group of 18 to 45 years old ${ }^{4}$. Tumor-forming PASH occurs predominantly in premenopausal women and generally presents clinically as a palpable, mobile, firm, and painless breast mass. However, occasional cases have occurred in postmenopausal women, men, adolescents, and even in pediatric patients ${ }^{5}$.

Clinical, mammographic and ultrasonographic findings are not specific and generally lead to a fibroadenoma or phyllodes tumor diagnosis ${ }^{6}$. Histopathogenesis is nuclear, and the literature reports that hormonal factors play a role in its development ${ }^{7}$. Although there are some reports of tamoxifen use, the treatment recommended by most authors is an excision of the lesion ${ }^{8}$. Breast reconstruction techniques, when combined with optimal surgical resection, contribute to an integral treatment for women, with preservation of sexuality and body image, and, consequently, a less traumatic rehabilitation process, bringing physical, psychological and social benefits9.

This study aimed to report a case of a patient with multiple bilateral solid nodules, whose histopathological diagnosis of the surgical piece was PASH, and who was surgically treated by bilateral adenectomy and immediate breast reconstruction using Thorek's technique (amputation and free grafting of the aorta-nipple complex). The patient had an excellent cosmetic result, was free of relapses until the present moment, and was treated in the Mastology Clinic of Santa Casa de Belo Horizonte.

\section{CASE REPORT}

Patient E.S.F., female, 40 years old, multiparous (G3P3A0), with a family history of a mother who died of breast cancer at 42 years of age, was referred to Santa Casa de Belo Horizonte in October 2014. She had reports of multiple bilateral breast nodules of progressive growth for 4 years, which was associated with mastalgia, hypertrophy and mammary ptosis. She denied the use of combined oral contraceptives (OCs) or hormone replacement therapy and presented a history of benign nodule excision in both breasts.
Clinical examination demonstrated asymmetric, hypertrophic breasts, grade III ptosis, with multiple nodules bilaterally, dermal suffering by compression, and no lymph node enlargement (Figures 1A and 1B).

Mammography was performed on 10/24/2013, which showed dense breasts with glandular components of bilateral multinodal morphology. Ultrasonography on 08/21/2014 demonstrated multiple nodular images, distorting breast architecture with irregular contours and shapes and, finally, core biopsy with a histological diagnosis of benign, fibroepithelial lesion with focal cell proliferation. Surgical removal was indicated.

In view of the positive family history for breast carcinoma, the patient's clinical condition, the histological diagnosis and the surgical impossibility of removing only the tumors (as they fully occupied both breasts), the treatment chosen was adenectomy and immediate reconstruction with an anatomical mammary prosthesis implant, with a volume of 300 cc bilaterally. Thorek's technique (amputation and free graft of the aorta-nipple complex) was used, which is associated with the construction of the lower dermal flap.

An histopathological examination confirmed the diagnosis of PASH. The resected mammary volume was $1,502 \mathrm{~g}$ in the right breast and 1,377 $\mathrm{g}$ in the left breast (Figures 2A and 2B).

The patient had a good postoperative evolution, and the drain removed on the $6^{\text {th }}$ postoperative day (POD). Sponge dressings were removed on the $11^{\text {th }}$ POD (Figures $3 \mathrm{~A}$ and $3 \mathrm{~B}$ ).

The patient evolved with depigmentation of the nipple-areola complex (NAC) (Figures 4A and 4B) and underwent surgical refinement with dermopigmentation and remodeling of the inframammary sulcus after eight months (Figures 5A and 5B).

Outpatient follow-up was maintained with excellent aesthetic results and no signs of local recurrence after 19 months.
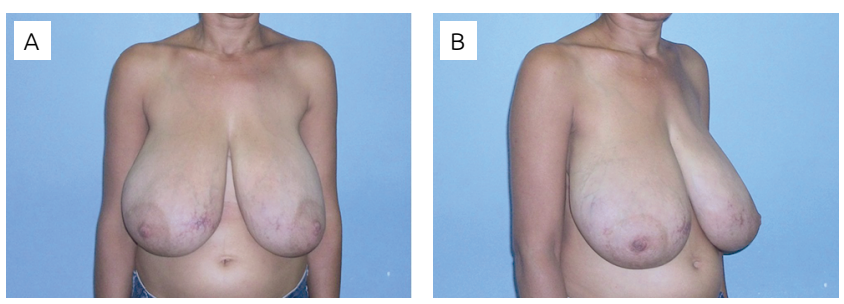

Figure 1. Preoperatively. Multiple bilateral nodules associated with hypertrophy and mammary ptosis: (A) frontal view; (B) oblique view at $45^{\circ}$ to the right.
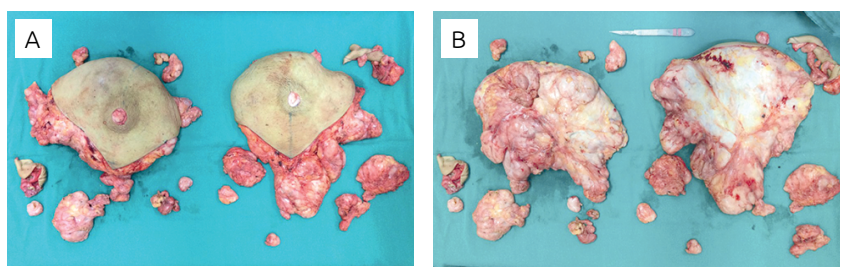

Figure 2. Perioperatively. Bilaterally resected surgical specimen: (A) anterior face; (B) posterior face. 

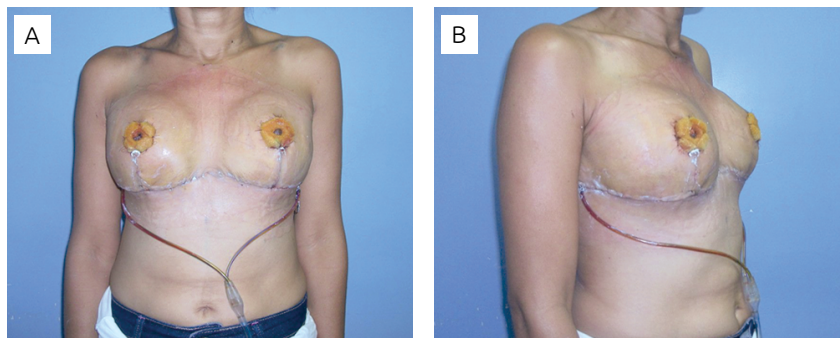

Figure 3. Fourth postoperative day: (A) frontal view; (B) oblique view at $45^{\circ}$ to the right.
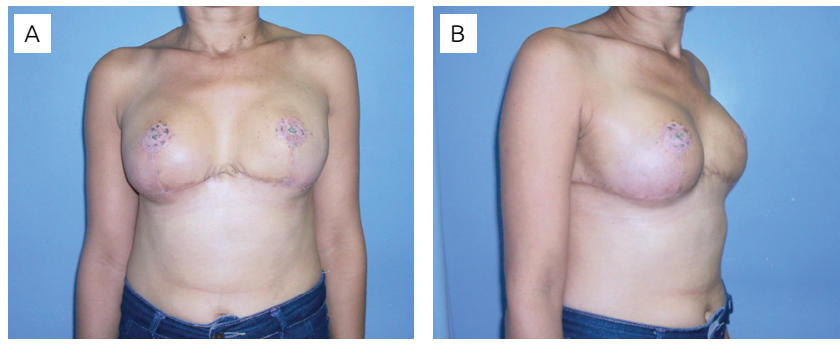

Figure 4. Two months postoperatively evolving with loss of nipple-papillary complex graft: (A) frontal view; (B) oblique view at $45^{\circ}$ to the right.
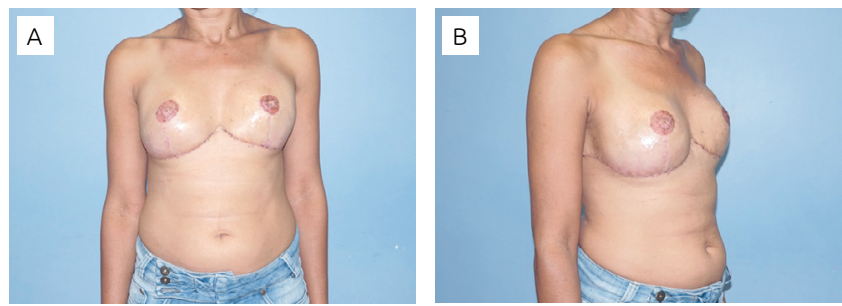

Figure 5. Postoperatively. Ten days after the nipple-papillary complex dermopigmentation and the inframammary flap repositioning: (A) frontal view; (B) oblique view at $45^{\circ}$ to the right.

\section{METHODOLOGY}

For the case study, an analysis of the patient's chart was performed in conjunction with the gathering of their clinical history, laboratory and imaging tests, which aided in the diagnosis and follow-up of their pre, per, and postoperative evolution.

A bibliographic review was carried out through active searches in the following databases: CAPES portal, Pubmed and UpToDate.

\section{DISCUSSION}

PASH is an uncommon but benign breast lesion that affects women aged between 18 and 45 years old. It can be found incidentally on routine biopsies performed for benign or malignant breast diseases, or it present itself as clinically and mammographically evident breast masses ${ }^{3,5}$.
Its pathogenesis is unclear, although some authors suggest that it could be an aberrant response from myofibroblasts to endogenous or exogenous hormonal stimuli. This could happen particularly from progesterone, which begins with a marked focal breast change, a physiological occurrence during the menstrual cycle $^{10}$. It affects women primarily in the premenopausal period, but the literature also reports PASH in women in the postmenopausal period with hormone replacement therapy ${ }^{11}$, as well as in men with gynecomastia, which also supports a hormonal-based nature of these lesions ${ }^{4}$.

It appears clinically as a circumscribed, painless, palpable nodule, with a firm or soft consistency, and elongated or oval in shape, similar to benign solid nodules. It occasionally exhibits rapid growth and may occur bilaterally ${ }^{12}$.

There is no specific mammographic or ultrasonographic aspect for PASH. With mammography, it is shown as a mass of well-defined or partially defined margins, and nodules with indistinct or spiculated margin have also been reported. According to ultrasonography, most of the lesions identified are solid and hypoechogenic, with some heterogeneous lesions ${ }^{13,14}$.

PASH's characteristic histological aspect consists of empty, anastomosed fissure spaces that permeate dense and hyalinized connective tissue in the interlobular and/or intralobular stroma. These pseudovascular channels are surrounded by fusiform myofibroblastic cells ${ }^{13}$. This can be inferred by immunohistochemistry, which demonstrates positivity for CD34, vimentin, actin, smooth muscle desmin and bcl-2 $24^{13}$.

Among the differential diagnoses, the most important is low-grade angiosarcoma, which is identified by the presence of anastomosed vascular channels containing red blood cells that invade the breast tissue and are not associated with a collagen stroma ${ }^{15}$. The stromal cells in PASH generally have a benign nuclear appearance, in contrast to the atypical appearance of angiosarcoma.

Due to cellularity, PASH can also be confused with phyloid tumors, although they do not have the typical abnormal glandular configuration of this tumor. Finally, it is possible to mistake PASH for fibroadenoma if the pseudovascular spaces are not recognized ${ }^{10}$.

A definitive histological diagnosis can be performed by an excisional or core needle biopsy. Although some authors recommend the excision of the lesion to evaluate the possibility of associated fibroepithelial neoplasia, when the use of a core needle identified PASH ${ }^{13}$, Cohen et al. reports that if the imaging findings are consistent with breast PASH, confirming the diagnosis with a surgical biopsy is not required ${ }^{14}$.

A vacuum-assisted biopsy, although not routinely applied for complete excision, can be safe and useful when a specific and precise diagnosis is necessary.

To date, there is only one reported case that suggests a malignant transformation of a PASH lesion, and only rare cases 
have been reported in which this pathology was associated with malignancy ${ }^{16}$.

The treatment recommended by most authors is extensive local excision. A recently published study has shown that non-surgical management strategies can be considered for patients who refuse surgical procedures, and these options may be acceptable especially when the lesion is small and a triple assessment has been performed to exclude a malignant disease $^{17}$. Some reports have shown an impressive response to tamoxifen in a patient with breast enlargement, pain and breast masses ${ }^{8}$. However, prolonged use may not be ideal, considering the possible side effects.

A mastectomy has been reported to control multiple nodular recurrence ${ }^{18,19}$. The rates of PASH relapse after excision are rare and range from 15 to $22 \%$, and the prognosis is excellent ${ }^{1,18}$.

The above reported case of an uncommon clinical presentation shows a patient with multiple bilateral nodules with progressive growth, which associated with hypertrophic ptotic mastopathy. This caused great discomfort and patient dissatisfaction. Because the histopathological diagnosis of core biopsy was not definitive, and considering the family history of breast neoplasm and the clinical condition of the patient, surgical resection was chosen. This consisted of a bilateral adenectomy and immediate reconstruction with an anatomical prosthesis using Thorek's technique and a dermal flap technique, followed by surgical refinement with a nipple-papillary complex dermopigmentation and a repositioning of the inframammary fold eight months after the first surgery. The proposed treatment had the following objectives:

- Complete resection of lesions for a definitive diagnosis;

- Improvement in the patient's symptomatology;

- Preservation of body image with physical, psychological and social benefits.

\section{CONCLUSION}

PASH is a rare, benign mammary pathology that often presents itself as a nodular mass with progressive growth, which can cause painful symptoms and deformities in the breast. It predominantly affects premenopausal women, and its pathogenesis is related to hormonal stimulation. There is no specific clinical or radiological change, but the association of these factors is essential for its diagnosis.

Although there are reports of tamoxifen treatment, the recommended course of action is surgery, which, when associated with breast reconstruction, is an excellent option for cases of bulky masses, multiple lesions and large deformities in the breast, resulting in a significant improvement in quality of life. Most of the reports published so far refer to radiological aspects, the pathology, and a series of PASH cases. Few cases of surgical resection followed by immediate breast reconstruction have been published.

\section{REFERENCES}

1. Vuitch MF, Rosen PP, Erlandson RA. Pseudoangiomatous hyperplasia of mammary stroma. Hum Pathol. 1986;17(2):185-91.

2. Wieman SM, Landercasper J, Johnson JM, Ellis RL, Wester SM, Lambert PJ, et al. Tumoral pseudoangiomatous stromal hyperplasia of the breast. Am Surg. 2008;74:1211-4.

3. Ibrahim RE, Sciotto CG, Weidner N. Pseudoangiomatous hyperplasia of mammary stroma. Some observations regarding its clinicopathologic spectrum. Cancer. 1989;63:1154-60.

4. Milanezi MF, Saggioro FP, Zanati SG, Bazan R, Schmitt FC. Pseudoangiomatous hyperplasia of mammary stroma associated with gynaecomastia. J Clin Pathol. 1998;51:204-6.

5. Shehata BM, Fishman I, Collings MH, Wang J, Poulik JM, Ricketts RR, et al. Pseudoangiomatous stromal hyperplasia of the breast in pediatric patients: an underrecognized entity. Pediatr Dev Pathol. 2009;12:450-4. https://doi.org/10.2350/0809-0528.1

6. Hargaden GC, Yeh ED, Georgian-Smith D, Moore RH, Rafferty EA, Halpern EF, et al. Analysis of the mammographic and sonographic features of pseudoangiomatous stromal hyperplasia. AJR Am J Roentgenol. 2008;191:359-63. https:// doi.org/10.2214/AJR.07.2479
7. AbdullGaffar B. Pseudoangiomatous stromal hyperplasia of the breast. Arch Pathol Lab Med. 2009;133:1335-8. https://doi. org/10.1043/1543-2165-133.8.1335

8. Pruthi S, Reynolds C, Johnson RE, Gisvold JJ. Tamoxifen in the Management of Pseudoangiomatous Stromal Hyperplasia. Breast J. 2001;7(6):434-9.

9. Audretsch WP, Rezai M, Kolotas C, Zamboglou N, Schnabel T, Bojar H. Tumor-Specific Immediate Reconstruction in Breast Cancer Patients. Seminars Plastic Surgery. 1998;11(1):71-100. DOI: $10.1055 / \mathrm{s}-2008-1080243$

10. Cyralk D, Carpenter PM. Breast imaging case of the day. Pseudoangiomatous stromal hyperplasia. RadioGraphics. 1999; 19:1086-8. https://doi.org/10.1148/radiographics.19.4.g99j1201086

11. Anderson C, Ricci A Jr., Pedersen CA, Cartun RW. Immunocytochemical analysis of estrogen and progesterone receptors in benign stromal lesions of the breast. Evidence for hormonal etiology in pseudoangiomatous hyperplasia of mammary stroma. Am J Surg Pathol. 1991;15:145-9.

12. Ryu EM, Whang IY, Chang ED. Rapidly growing bilateral pseudoangiomatous stromal hyperplasia of the breast. Korean J Radiol. 2010;11(3):355-8. DOI: 10.3348/kjr.2010.11.3.355 
13. Chagas CR, Menke CH, Vieira RJS, Boff RA. Tratado de mastologia da SBM. Rio de Janeiro: Revinter; 2011. p.479-81.

14. Cohen MA, Morrison EA, Rosen PP, Dershaw DD, Liberman L, Abramson AF. Pseudoangiomatous stromal hyperplasia: mammographic, sonographic and clinical patterns. Radiology. 1996;198:117-20. https://doi.org/10.1148/radiology.198.1.8539361

15. Kopans D. Breast Imaging. Filadélfia: Lippincott-Raven Publishers; 2007.

16. Nassar H, Elieff MP, Kronz JD, Argani P. Pseudoangiomatous stromal hyperplasia (PASH) of the breast with foci of morphologic malignancy: a case of pash with malignant transformation? Int J Surg Pathol. 2010;18:564-9. https://doi. org/10.1177/1066896908320835

17. Sng KK, Tan SM, Mancer JF, Tay KH. The contrasting presentation and management of pseudoangiomatous stromal hyperplasia of the breast. Singapore Med J. 2008;49:e82-5.

18. Powell CM, Cranor ML, Rosen PP. Pseudoangiomatous stromal hyperplasia (PASH). A mammary stromal tumor with myofibroblastic differentiation. Am J Surg Pathol. 1995;19:270-7.

19. Piccoli CW, Feigi SA, Palazzo JP. Developing asymmetric breast tissue. Radiology. 1999;211:111-7. https://doi.org/10.1148/ radiology.211.1.r99ap42111 